\title{
Daniels v Canada: Supreme Court Ends 150 Years of Political Football
}

\author{
Keltie Lambert*
}

\section{Introduction}

On October 8, 2015, after more than 14 years of litigation, the Supreme Court of Canada heard arguments in the Daniels case, which centers around the fundamental question of whether the term "Indians" as used in section 91(24) of the Constitution Act, 1867 includes Métis and Non-status Indians. ${ }^{1}$ In seeking various declarations, the Plaintiffs hoped to bring to an end a longstanding jurisdictional dispute between the Provinces and Canada that resulted in Métis and Non-status Indians being treated like "political footballs."

The purpose of this short summary is to provide the reader with background information and to describe the submissions of the Metis Settlements General Council as intervener. It should be noted that the case raises a number of issues not addressed in this paper that may nonetheless be of interest to the constitutional bar regarding the Court's power to grant declaratory relief, including whether and how to apply the interpretive principles (are progressive and purposive interpretation two sides of the same coin?), along with the ongoing dialogue between Canadian citizens, Parliament, and the Court.

\section{Federal Court Trial Decision}

The Federal Court of Canada released its decision in Daniels $v$ Canada, 2013 FC 6 in January
2013. The lawsuit was brought by the Congress of Aboriginal Peoples and individual Plaintiffs ${ }^{3}$ ("CAP") against Canada. The Plaintiffs sought three declarations:

(a) that Métis and non-status Indians are "Indians" within the meaning of the expression "Indians, and lands reserved for the Indians" in section 91(24) of the Constitution Act, 1867 (the "First Declaration") ${ }^{4}$

(b) that the Queen (in right of Canada) owes a fiduciary duty to Métis and nonstatus Indians as Aboriginal people (the "Second Declaration")

(c) that the Métis and non-status Indian peoples of Canada have the right to be consulted and negotiated with, in good faith, by the federal government on a collective basis through representatives of their choice, respecting all their rights, interests, and needs as Aboriginal peoples (the "Third Declaration"). ${ }^{6}$

The scale of the trial was massive in historical scope, evidence presented, and costs incurred. In the words of the trial judge, "The canvas over which the parties have painted the answer [to the issue of whether Métis are "Indians" within the meaning of s. 91(24)] encompasses Canadian history virtually from the time of Champlain in Passamaquoddy Bay in 1603 to the present day." The record presented at trial constituted more 
than 15,000 pages, with the Plaintiff presenting 452 exhibits, and the Defendant producing 327 exhibits. There were 28 days of trial resulting in 4,852 pages of transcripts. ${ }^{8}$ At the time of trial, "the public ha[d] already advanced approximately \$2 million to the Plaintiffs even with Plaintiffs' counsel's contribution of work at substantially below usual hourly rates. The government of Canada ha[d] also had to pay its Justice counsel and their experts."

In the result, the Federal Court trial judge declared:

those persons who are Métis and those who are non-status Indians as set forth in the Reasons for Judgment are 'Indians' within the meaning of the expression 'Indians and Lands reserved for the Indians' contained in s. 91(24) of the Constitution Act, $1867^{10}$

and refused to issue the Second and Third Declarations.

\section{Federal Court of Appeal}

In February 2013, Canada appealed to the Federal Court of Appeal and CAP cross-appealed the decision not to issue the Second and Third Declarations. Métis Settlements General Council, Gift Lake Métis Settlement, the Attorney General of Alberta, Métis National Council, Manitoba Métis Federation, and Métis Nation of Ontario all applied for and were granted Intervener status at the Federal Court of Appeal.

Neither Party challenged any of the Trial Judge's findings of fact. At issue was the Parties' differing interpretation of the historic record and subtle differences in approaching the issue of constitutional interpretation. The Court heard much argument on whether granting the First Declaration would have any practical utility, given the generally accepted principle that Parliament has no duty to act on its jurisdiction.

Of particular interest to Métis Settlements General Council (MSGC) was Canada's argument that the Court should refrain from granting the First Declaration because doing so may put the Metis Settlements Act, ${ }^{11}$ and associated legislation at risk of being declared ultra vires the Province of Alberta. MSGC's intervention at the Federal Court of Appeal addressed allaying any concerns in this regard by focussing the Court on recent decisions from the Supreme Court which emphasize co-operative federalism over watertight jurisdictional compartments. ${ }^{12}$

Some Interveners on Appeal took issue with the way in which the Trial Judge defined the term "Métis" for the purposes of section 91(24). These submissions appear to have persuaded the Court of Appeal to arrive at a modified definition of Métis in its reasons for judgment, which reference the definition of Métis formulated in $R$ $v$ Powley, ${ }^{13}$ a section 35 Métis harvesting rights case.

On April 17, 2014, the Federal Court of Appeal released its decision which upheld but modified the First Declaration to remove the reference to 'non-status Indians.' The modified declaration was as follows: "The Métis are included as 'Indians' within s. 91(24) of the Constitution Act, 1867."14

The Federal Court of Appeal confirmed the trial judge's decision to dismiss the Second and Third Declarations.

\section{Supreme Court of Canada}

CAP sought leave to appeal to the Supreme Court of Canada seeking restoration of the trial judge's First Declaration (which included Non-Status Indians) and granting of the Second and Third Declarations. Canada sought conditional leave to cross-appeal the granting of the First Declaration. The Supreme Court of Canada granted both the Leave to Appeal and Conditional Leave to Cross-Appeal applications.

Twelve parties applied for Leave to Intervene. The Supreme Court granted intervener status to file written submissions to four parties ${ }^{15}$ and intervener status to make written and oral submissions to eight parties including: Attorney General of Alberta, Attorney General 
of Saskatchewan, Assembly of First Nations, Métis Settlements General Council, Gift Lake Métis Settlement, Métis National Council, Métis Federation of Canada, and Aseniwuche Winewak Nation. Only the Attorney General of Alberta supported Canada's cross-appeal and argued that Métis are not included within section 91(24).

Amongst the interveners representing Métis peoples, the Court of Appeal's modification of the Trial Judge's definition of Métis sparked significant debate. To compare, the Trial Judge stated as follows:

In the modern era, the difficulty of definition in part has been addressed. As indicated earlier, the government in 1980 defined the core group of MNSI as a group of native people who maintained a strong affinity for their Indian heritage without possessing Indian status. Their "Indianness" was based on self identification and group recognition ${ }^{16}$

Whereas the Court of Appeal stated at paragraphs 97 and 99:

This is reflected in the jurisprudence of the Supreme Court of Canada in Powley, Cunningham and Manitoba Métis Federation. In Powley, the Supreme Court did not exhaustively define who were included in the term Métis for the purpose of section 35 of the Constitution Act, 1982. However, as discussed above, the Court rejected the notion that the term Métis encompassed all individuals with mixed Indian and European heritage. Instead, the term refers to a distinctive group of people who developed separate and distinct identities. The three broad factors that are the indicia of Métis identity for the purpose of claiming Métis rights under section 35 were found to be: self-identification, ancestral connection and community acceptance (Powley, at paragraphs 31 to 33$)$.

$[\ldots]$

It follows that the criteria identified by the Supreme Court in Powley inform the understanding of who the Métis people are for the purpose of the division of powers analysis. The Powley criteria are inconsistent with a race-based identification of the Métis." ${ }^{17}$
From MSGC's perspective, the Federal Court of Appeal gravitated too quickly to Powley without contemplating the different constitutional purposes of section 35 and section 91(24) and without considering the legal and practical implications that may arise from a prematurely narrow definition of Métis for the purposes of defining Parliament's jurisdiction. Specifically, MSGC raised the following concerns:

- Powley was not intended by the Supreme Court to establish one definition of Métis for all purposes ${ }^{18}$;

- Section 35 and section 91(24) serve different constitutional purposes. While Powley limits the application of section 35 to communal rights holders within specific geographic locations, section $91(24)$ is not so limited ${ }^{19}$; and

- Inclusion of geographic and/or historic elements from Powley may constrain Parliament's jurisdiction and may lead to anomalous results for the Métis Settlements, given their unique history - including the potential that Métis Settlement members may be defined as "Métis" for the purposes of provincial legislation, but not defined as Métis for purposes of federal jurisdiction.

MSGC advanced the idea that the Métis hold the primary right and responsibility to define themselves and that, where such definitions exist, they should be respected by Parliament. Further, the definition and membership process in the $M S A$ are the result of extensive negotiations between Alberta and the Métis Settlements spanning over eighty years. The definition of Métis and the objective requirements to prove a person meets the definition of Métis contained in the MSA are consistent with the Supreme Court's direction to achieve standardization, self-definition, and an objective process for identifying Métis people. ${ }^{20}$

The Supreme Court's ruling was released on April 14, 2016, after the Constitutional Law Symposium at which a version of this paper was 
first presented. ${ }^{21}$ The Supreme Court reinstated the First Declaration to include both nonStatus Indians and Métis within Parliament's jurisdiction under section 91(24). It declined to grant the second and third Declarations for essentially the same reasons as the Courts below: the second and third Declarations were a restatement of the existing law and thereby served no useful purpose. ${ }^{22}$

In addition, the Supreme Court returned to the Trial Judge's broader conception of how to identify the Métis people and communities included within section 91(24) finding there "is no need to delineate which mixed-ancestry communities are Métis and which are nonstatus Indians. They are all "Indians" under section 91(24) by virtue of the fact that they are all Aboriginal peoples." ${ }^{23}$ Specifically, the Supreme Court stepped back from a restrictive application of the definitional criteria in Powley concluding that section 35 and section 91(24) serve very different constitutional purposes and there is "no principled reason for presumptively and arbitrarily excluding certain Métis from Parliament's protective authority on the basis of the third criterion, a 'community acceptance' test." 24

Finally, of great interest to the Métis Settlements and the constitutional bar in Alberta, the Supreme Court specifically confirmed that declaring Métis to be included in section 91(24) does not mean that all provincial legislation related to the Métis is inherently ultra vires. Rather, in keeping with the Court's previous decisions in Canadian Western Bank, ${ }^{25}$ and NIL/ TU,O Child and Family Services, ${ }^{26}$ provincial legislatures may continue to establish valid provincial schemes so long as they do not impair the core of the "Indian" power. ${ }^{27}$

\section{Conclusion}

The release of the Supreme Court's decision in April 2016 was hailed as a victory by MSGC and the other Métis participants. The decision respects the distinctiveness of Canada's three Aboriginal Peoples ${ }^{28}$ while recognizing that rec- onciliation will not be easily achieved by the imposition of arbitrary categories. While a significant amount of work remains to achieve reconciliation between the Métis and the Crown, the Supreme Court's decision in Daniels should provide a solid foundation from which to move forward.

\section{Endnotes}

* Partner, Witten LLP, The views expressed by the presenter are hers alone and not necessarily those of her client, Metis Settlements General Council.

1 The term Non-Status Indians generally refers to persons who are First Nations people but who do not fit within the current definition of "Indian" under the Indian Act, RSC 1985 c I-5.

2 See Daniels $v$ Canada, 2013 FC 6 at paras 86, 107 [Daniels Trial].

3 Harry Daniels, Gabriel Daniels, Leah Gardner and Terry Joudrey.

4 Daniels Trial, supra note 2 at para 3.

5 Ibid.

6 Ibid.

7 Ibid at para 2.

8 Application for Leave to Appeal to the Supreme Court of Canada, case number 35945 at para 13.

9 The Court considered the overall financial public investments in the Advance Costs Order (Daniels $v$ Canada (Minister of Indian Affairs and Northern Development), 2011 FC 230), with a rough estimate of \$5-6 million (Daniels Trial, supra note 2 at para 79).

10 Order Judgment of Justice Phelan dated January 8, 2013, Court file number T-2172-99.

11 RSA 2000 c M-14 [MSA]. The Métis Settlements are the only Métis with a land base and system of self-governance which is protected by provincial legislation and an amendment to the Constitution of Alberta. For more background on the Métis Settlements see Alberta (Aboriginal Affairs and Northern Development) $v$ Cunningham, 2011 SCC 37, [2011] 2 SCR 670 [Cunningham]; Metis Settlements Land Protection Act, RSA 2000, c M-16; Métis Settlements Accord Implementation Act, RSA 2000, c M-15; Constitution of Alberta Amendment Act, 1990, RSA 2000, c C-24 [Constitution of Alberta Amendment Act]; and Metis Settlements General Council, "Homepage", online: MSGC $<$ www.msgc.ca $>$. 
12 Note, at the SCC Canada abandoned its arguments regarding the potential for the MSA and associated legislation to be rendered ultra vires.

132003 SCC 43, [2003] 2 SCR 207 [Powley].

14 Order of the Federal Court of Appeal dated April 17, 2014, Court file number A-49-13.

15 Te’mexw Treaty Association; Chiefs of Ontario; Native Council of Nova Scotia, New Brunswick Aboriginal Peoples Council and Native Council of Prince Edward Island (jointly); Native Alliance of Quebec (Alliance Autochtone du Québec).

16 Daniels Trial, supra note 2 at para 117.

17 Canada (Indian Affairs) v Daniels, 2014 FCA 101, [2014] 4 FCR 97.

18 See Powley, supra note 13 at para 30.

19 See Daniels Trial, supra note 2 at para 544; Powley, supra note 13 at paras 18, 29; $R v$ Van der Peet, [1996] 2 SCR 507 at para 31, 4 CNLR 177; and Attorney General of Canada $v$ Canard, [1976] 1 SCR 170 at para 79, 52 DLR (3d) 548 [Canard].
20 See MSA, supra note 11, ss 1(j), 76; Constitution of Alberta Amendment Act, supra note 11, Preamble; Powley, supra note 13 at para 29; Cunningham, supra note 11 at para 82; and Canard, supra note 19 at para 79 .

21 Daniels $v$ Canada (Indian Affairs and Northern Development), 2016 SCC 12 [Daniels SCC].

22 Ibid at paras 52-57.

23 Ibid at para 46.

24 Ibid at para 49.

25 Canadian Western Bank v Alberta, 2007 SCC 22, [2007] 2 SCR 3.

26 NIL/TU,O Child and Family Services $v$ BC Government and Services Employee Union, 2010 SCC 45, [2010] 2 SCR 696.

27 Daniels SCC, supra note 21 at para 51.

28 Ibid at para 42. 
